Dr IVANA DOBRIVOJEVIĆ, viši naučni saradnik

Institut za savremenu istoriju

Beograd, Trg Nikole Pašića 11, Republika Srbija

ivanadobrivojevic@hotmail.com

originalan naučni rad

UDK: $316.356 .2(497.1) " 1945 / 1974 "$

primljeno: 1. april 2017.

354.84/.85(497.1)"1945/1974"

prihvaćeno: 11. oktobar 2017.

316.662-055.2(497.1)"1945/1974"

DOI: 10.29362/IST20VEKA.2018.1.DOB.119-132

\title{
ZA ŽELJENO RODITELJSTVO. DRŽAVNA POLITIKA JUGOSLAVIJE U OBLASTI PLANIRANJA PORODICE 1945-1974.*
}

APSTRAKT: Rad razmatra državnu politiku socijalističke Jugoslavije na polju planiranja porodice. Posebna pažnja je posvećena obrazovanju tela koja su se ovim poslom bavila, propagiranju željenog roditeljstva, kontracepciji kao i naporima da liberalizovani abortus prestane da bude (osnovna) metoda kontrole rađanja.

KLJUČNE REČI: Jugoslavija, Savezni savet za planiranje porodice, abortus, željeno roditeljstvo, Rezolucija o planiranju porodice

U siromašnoj i agrarno prenaseljenoj Kraljevini Jugoslaviji veliki prirodni priraštaj od oko 200.000 lica godišnje predstavljao je ekonomsko i socijalno opterećenje. Ipak, demografske prilike su varirale od regiona do regiona. Dok su u Sremu i Banatu već 30-ih godina 20. veka preovladavale porodice sa dvoje dece, u selima Sandžaka i Bosne porodice sa osmoro, desetoro ili dvanaestoro dece nisu predstavljale nikakvu retkost. Što su životne prilike bile skromnije, privreda naturalnija, nepismenost izraženija, a udaljenost od kulturnih i ekonomskih centara veća, rasla je i stopa rađanja. Neslavan rekord držala je Vrbaska banovina u kojoj je natalitet bio jedan od najvećih u svetu. ${ }^{1} \mathrm{U}$ takvim okolnostima, nestručno obavljen pobačaj postao je jedini metod kontrole rađanja. Iako je Krivični zakonik donet 1929. godine zabranjivao abortus i pretio zatvorskim kaznama ženi, izvršiocu pobačaja, pa čak i lekarima koji su nestručno započet pobačaj završili a da nisu obavestili vlasti, ${ }^{2}$ pobačaj je (p)ostao deo sva-

\footnotetext{
* Rad je deo projekta Srpsko društvo u jugoslovenskoj državi u 20. veku: između demokratije i diktature (177016), koji finansira Ministarstvo prosvete, nauke i tehnološkog razvoja Republike Srbije.

${ }^{1}$ Ратибор В. Поповић, Аграрна пренасељеност Југославије (Београд: Геца Кон, 1940), 20-21, 32.

${ }^{2}$ Кривични законик за Краљевину Срба, Хрвата и Словенаиа (Београд: Државна штампариja, 1929). Videti i: Гордана Дракић, „Прекид трудноће према Кривичном законику Краљевине Југославије и пројектима који су му претходили”, Зборник радова Правног факултета у Новом Саду, бр. 3, (2011), 533- 542.
} 
kodnevice jugoslovenske žene. Topli crep, koren od kukureka ${ }^{3}$ i ženetrga, vreteno i igle za pletenje predstavljali su samo neke od improvizovanih rekvizita za vršenje abortusa. ${ }^{4}$ Ipak, Krivični zakonik je doneo i jednu važnu novinu. Iako se na abortus gledalo kao na kriminalan akt, prvi put je dozvoljen prekid trudnoće iz medicinskih razloga. Odluku o postojanju medicinske indikacije donosile su lekarske komisije čiji je rad bio regulisan posebnom uredbom donetom 1930. Prepoznavanje medicinske indikacije omogućilo je prvi put nekažnjeno vršenje pobačaja u lekarskim ordinacijama. ${ }^{5}$

Istraživanja koja je 30-ih godina prošlog veka obavio Aleksandar Petrović u Rakovici, tada selu nadomak Beograda, pokazala su da su žene verovale da pobačaj nije „greh“ s obzirom na to da dete „nije živo jer se još uvek nije rodilo“. „Ja ostajem svaki drugi mesec u drugom stanju“, govorila je jedna meštanka. „Samo neću da rodim, jel' šta će mi tol'ko dece...I sad pobacujem svaki drugi mesec“. „Zašto poturujemo decu?“, pričala je druga. „Ne trebaju nam. Imamo ih dosta. Dete treba odhraniti, odnegovati, školovati, a ja nemam od čega". ${ }^{6}$ I dok su imućne gradske dame mogle izvršiti pobačaj u ordinacijama onih lekara koji su bili spremi da „zanemare“ stroge propise, ${ }^{7}$ seljanke su bile prinuđene da neželjenu trudnoću pokušaju da okončaju ,kod za to čuvenih žena u selu, pa čak i samostalno". ${ }^{8}$ Suočeni sa slučajevima teških krvarenja i trovanja i rastućim brojem smrtnih ishoda, lekari su se na 17. kongresu Srpskog lekarskog društva založili da se izmene članovi Krivičnog zakonika koji su se odnosili na pobačaj, to jest da se uvaže ,socijalno-ekonomski, duševno higijenski i rasno biološki momenti“.9

Posle oslobođenja, u delimično izmenjenim političko-ekonomskim okolnostima, nove vlasti su nastavile sa prenebregavanjem problema ilegalnih pobačaja koji su poprimali razmere epidemije. Upravo kao i u Sovjetskom Savezu, mnogi partijski funkcioneri pobačaj nisu smatrali pravom žene već „sredstvom“ koji će država dozvoljavati sve dok to bude neophodno. Štaviše, pre dolaska na vlast, pojedini komunisti su smatrali da pobačaj treba liberalizovati samo u kapitalističkim zemljama. U socijalizmu, verovali su, abortus će biti

\footnotetext{
${ }^{3}$ Vera Gudac-Dodić, „Položaj žene u Srbiji (1945-2000)“, u: Žene i deca 4. Srbija u modernizacijskim procesima XIX i XX veka, bez navedenog urednika (Beograd: Helsinški odbor, 2006), 41.

${ }^{4}$ Александар Петровић, Раковииа. Соиијално-здравствене и хигијенске прилике, т. 2 (Београд: Централни хигијенски завод, 1939), 28-29.

${ }^{5}$ Arhiv Jugoslavije (AJ), fond 142/II, Socijalistički savez radnog naroda Jugoslavije (SSRNJ), fascikla 417, A. Milojković, G. Žarković, M. Džumhur, Historijat liberalizacije pobačaja u Jugoslaviji. Savetovanje o izgradnji društvenih stavova o populacionoj politici u Jugoslaviji (1973).

${ }^{6}$ А. Петровић, Раковища. Соиијално-здравствене и хигијенске прилике, т. 2, 28-29.

${ }^{7}$ AJ, 142/II-417, A. Milojković, G. Žarković, M. Džumhur, Historijat liberalizacije pobačaja u Jugoslaviji. Savetovanje o izgradnji društvenih stavova o populacionoj politici u Jugoslaviji (1973).

${ }^{8}$ Momčilo Isić, „Dete i žena na selu u Srbiji između dva svetska rata”, u: Žene i deca 4. Srbija u modernizacijskim procesima XIX $i$ XX veka, 152.

${ }^{9}$ Предраг Ј. Марковић, „Сексуалност између приватног и јавног у 20. веку“, у: Приватни живот код Срба у 20. веку, уредник Милан Ристовић (Београд: Clio, 2007), 115.
} 
nepotreban budući da će država brinuti o majkama i deci. ${ }^{10}$ Međutim, zabrinjavajući zdravstveni izveštaji koji su pristizali iz gotovo čitave zemlje svedočili su o sve većem broju smrtnih slučajeva nastalih usled nestručno izvedenih pobačaja. Stoga je Komitet za zaštitu narodnog zdravlja FNRJ zatražio od svih lekarskih društava i ginekoloških sekcija da uobliče svoje stavove o pitanju prekida neželjene trudnoće. Profesor dr Franc Novak je postavljen za referenta po pitanju abortusa. On je sumirao stavove koji su se čuli u diskusijama na sastancima ginekoloških klinika u Beogradu, Zagrebu i Ljubljani kao i mišljenja iznesena u referatima eminentnih ginekologa tog vremena. Stav struke je bio da se abortus može vršiti najkasnije do tri meseca trudnoće, da se pobačaj ne sme izvoditi ambulantno već samo u određenim ustanovama, da socijalna indikacija ne može biti razlog za prekid trudnoće kao i da u pojam zabranjenog pobačaja ne treba ubrojiti kontracepciju. Iako su predlagači novog Krivičnog zakona prvobitno zastupali stanovište da treba kazniti i abortera i ženu nad kojom je izvršen pobačaj, ginekolozi su se založili za nekažnjavanje žena. Pošlo se od uverenja da bi u slučaju komplikacija usled nestručno obavljenog abortusa žene brže zatražile medicinsku pomoć, što bi uticalo i na smanjenje broja smrtnih ishoda. ${ }^{11}$

Prvi korak u pravcu liberalizacije abortusa predstavljalo je donošenje novog Krivičnog zakonika (1951) kojim je predviđen prestanak krivičnog gonjenja žene koja izvrši ili dozvoli da joj se izvrši abortus, a o tome se raspravljalo i na zasedanju Skupštine. ${ }^{12}$ Do 1952. godine pobačaj se mogao izvršiti u zdravstvenoj ustanovi isključivo ako su postojale medicinske ili kriminalne indikacije za prekid trudnoće. Ako bi ilegalan pobačaj bio otkriven, trudnica je mogla biti osuđena na do pet godina zatvora, a lice koje je izvršilo abortus na do 10 godina. ${ }^{13}$ Godine 1952. doneta je uredba na osnovu koje se, pored medicinskih razloga, u obzir mogu uzeti i određeni socijalni problemi. U prvoj godini njene primene, broj dozvoljenih pobačaja u odnosu na broj nedozvoljenih bio je veoma mali (10\%). ${ }^{14}$ Štaviše, sve do 1956 . godine komisije su pokazivale veliku krutost $u$ odlučivanju, što je uticalo na žene slabijeg imovinskog stanja da „pomoć“ traže od priučenih i nestručnih lica. ${ }^{15}$

Liberalizacija propisa izazvala je oprečna mišljenja među lekarima i rasplamsala polemiku tokom 1953. i 1958. godine. Na II kongresu ginekologa i akušera održanom oktobra 1953. konstatovano je da sprovođenje novog Krivičnog

\footnotetext{
${ }^{10}$ Ivan Simić, „Soviet Influences on Yugoslav Gender Policies, 1945-1955” (doktorska disertacija, UCL 2015), 81. www.discovery.ucl.ac.uk/1516066/1/thesis.pdf.

${ }^{11}$ AJ, 142/II-417, A. Milojković, G. Žarković, M. Džumhur, Historijat liberalizacije pobačaja u Jugoslaviji. Savetovanje o izgradnji društvenih stavova o populacionoj politici u Jugoslaviji (1973).

${ }^{12}$ AJ, 142/II-623, Informacija o rešavanju problema planiranja porodice u Jugoslaviji.

${ }^{13}$ Вера Гудац-Додић, „Жена у социјализму: сфере приватности“, у: Приватни живот код Срба у 20. веку, 195.

${ }^{14}$ AJ, 142/2-658, Planiranje porodice - potreba savremenog društva; AJ, 142/II-623, Savetovanje o problemima prekida trudnoće i kontracepcije (1963).

${ }^{15}$ Ivana Dobrivojević, „Planiranje porodice u Jugoslaviji 1945-1974“, Istorija 20. veka, br. 2, (2016), 87.
} 
zakonika nije ,imalo velikog uspeha“ i da usled toga ,imamo sve više teških i negativnih posledica po zdravlje žene“. Usvojena je Rezolucija u kojoj je zahtevano da se zaoštri Uredba o dozvoljenom pobačaju, da socijalna indikacija bude uvažena samo sa medicinskom, ali i da se kazni trudnica koja se odlučila na abortus. Traženo je da se proširi mreža savetovališta i dispanzera za žene i isticano da pobačaj, čak i kada je izvršen u bolnici, predstavlja ,tešku povredu za ženu, njeno zdravlje, kao i za njeno društveno stanje“. Rezoluciju, međutim, nisu prihvatili ni svi ginekolozi prisutni na kongresu. ${ }^{16}$ Štaviše, pokazalo se da su stavovi lekara, okupljenih na pomenutom kongresu, o pitanju kontracepcije bili prilično konzervativni, budući da se se na nju gledalo kao na depopulacijsku meru. ${ }^{17}$ Rasprava se prenela u društveno-političke organizacije, ali i na stranice Borbe. ${ }^{18}$

Pitanje pobačaja je i u narednim godinama predstavljalo kontroverznu temu. I dok su se pojedinci, poput profesora Bazale, zalagali za potpunu liberalizaciju pobačaja, ${ }^{19}$ drugi su zagovarali čak i njegovu potpunu zabranu. U Beogradu je maja 1958. održano savetovanje u organizaciji Saveznog zavoda za narodno zdravlje i Sekretarijata za narodno zdravlje Saveznog izvršnog veća. Učestvovali su ginekolozi, socijalni radnici, kao i predstavnici Saveza ženskih društava, Saveza sindikata, Crvenog krsta i drugih organizacija. Zadatak celokupne zdravstvene službe, kako je istaknuto, jeste da upozna sve slojeve stanovništva sa opasnostima koje nosi abortus kao metod kontrole rađanja i da kontracepciju učini dostupnom svakoj ženi. ${ }^{20}$ Odlučeno je da treba razvijati službu kontracepcije kao sastavni deo zdravstvene zaštite, graditi „humanije odnose među polovima“ budući da je „,iskorenjivanje abortusa dugotrajan proces“ koji se mora „rešavati sve dotle... dok se ne afirmiše preventiva“. 21

Pokušaji preventive, međutim, nisu urodili plodom. Industrijalizacija i urbanizacija su ubrzale seksualno oslobađanje mladih. Broj neželjenih trudnoća je rastao, abortus je ostao glavni „metod“ kontrole rađanja, a znatan procenat ilegalnih pobačaja ozbiljno je narušavao zdravlje dela ženske populacije. Suočene sa narastajućim problemom, vlasti su se okrenule daljoj liberalizaciji propisa, prateći istočnoevropski trend. ${ }^{22}$ Februara 1960. doneta je Uredba o uslovima i postupku za dozvoljavanje pobačaja. Prema novoj Uredbi, osim iz medicinskih razloga, abortus je bio dozvoljen i u slučajevima „kad se može očekivati

\footnotetext{
${ }^{16}$ AJ, 142/II-417, A. Milojković, G. Žarković, M. Džumhur, Historijat liberalizacije pobačaja u Jugoslaviji. Savetovanje o izgradnji društvenih stavova o populacionoj politici u Jugoslaviji (1973).

${ }^{17}$ AJ, 142/II-417, F. Novak, L. Andolšek, M. Kuštrin, I. Veter, Prikaz razvoja odnosa do celokupne problematike planiranja porodice u medicinskim krugovima. Savetovanje o izgradnji društvenih stavova o populacionoj politici u Jugoslaviji (1973).

${ }^{18}$ Вида Томшич, „Даља легализација абортуса прихватљиво решење?“, Борба, 17. 1. 1954.

${ }^{19}$ AJ, 142/II-417, Savetovanje o izgradnji društvenih stavova o populacionoj politici u Jugoslaviji, Beograd 1973.

${ }^{20}$ AJ, 142/II-623, Zaključci sa savetovanja po pitanju kontracepcije, Uredbe o postupku za vršenje dozvoljenog pobačaja i seksualnog vaspitanja, održanog u Beogradu od 7-9. maja 1958.

${ }_{21}^{21} \mathrm{AJ}, 142 / \mathrm{II}-623$, Informacija o rešavanju problema planiranja porodice u Jugoslaviji.

${ }^{22}$ Dagmar Herzog, Sexuality in Europe. A Twentieth - Century History (Cambridge: Cambridge University Press, 2011), 101. Videti i: I. Dobrivojević, $n$. $d ., 88$.
} 
da bi bremenita žena zbog rođenja deteta došla u teške lične, porodične ili materijalne prilike koje se na drugi način ne mogu otkloniti“". O zahtevima za dozvoljavanje pobačaja odlučivale su prvostepene i drugostepene komisije, obrazovane pri zdravstvenim ustanovama, pre svega pri opštim bolnicama, porodilištima i ginekološko-akušerskim klinikama. ${ }^{23}$ Sve žene koje su zahtevale prekid trudnoće bile su dužne da uz molbu podnesu i dokumentaciju vezanu za motiv zbog kojeg traže prekid trudnoće - ugovor o stanu iz koga se vidi da molilja živi u lošim stambenim prilikama ili pak potvrdu o broju dece. Prilikom rešavanja zahteva, komisije su uzimale u obzir bračno stanje molilje, broj dece u porodici, eventualno postojanje socijalnih bolesti, nerešeno stambeno pitanje i slično. Pobačaji su odobravani pre svega iz socijalnih, a ne medicinskih indikacija. Saglasnost za pobačaj u praksi nije davana uglavnom udatim ženama bez dece, ženama koje su se javljale svake godine i neudatim ženama za koje je procenjivano da imaju uslove da rode. ${ }^{24}$

Komisije su, nalagao je zakonodavac, trebale da deluju zdravstvenoprosvetno u smislu tumačenja opasnosti od pobačaja i upoznavanja žena sa prednostima prevencije neželjenog začeća. Preventivan i vaspitni rad je, međutim, izostao. Ginekolozi su se žalili da se pretvaraju u abortere, ${ }^{25}$ a neki su, iako za to nije bilo nikakvog pravnog osnova, vršili sterilizaciju ženama koje su više puta dolazile na abortus. U periodu 1957-1961. samo u Sloveniji su izvršene 2.122 sterilizacije. Socijalna indikacija je poslužila kao razlog za čak 1.606 sterilizacija koje su u gotovo polovini slučajeva (48,3\%) bile urađene zbog velikog broja dece. Pojedini ginekolozi su tako krenuli linijom manjeg otpora - pomoću sterilizacije su izbegavali ponavljajuće abortuse, ali i propagiranje zaštitnih sredstava koja bi umanjila mogućnost neplaniranog začeća. Ova praksa je potrajala sve do 1964. godine kada je na V kongresu ginekologa usvojeno stanovište da je sterilizaciju opravdano vršiti jedino iz medicinskih razloga. ${ }^{26}$

Donošenje Uredbe o uslovima i postupku za dozvoljavanje pobačaja odigralo je značajnu ulogu u pogledu smanjivanja broja ilegalnih abortusa, što je bio i njen osnovni cilj. Međutim, njeno primenjivanje je pratila i jedna nova tendencija - mnogi parovi su shvatili da je žena Uredbom dobila neograničeno pravo na prekid neželjene trudnoće, ${ }^{27}$ pa je abortus nastavio da bude ,osnovni metod regulisanja porođaja“. ${ }^{28}$ Ovakvom shvatanju je pogodovala ne samo neobaveštenost i nezainteresovanost stanovništva, već i državna politika. Paradoksalno, Uredba je dozvolila široke mogućnosti pobačaja, a oskudan izbor kontra-

\footnotetext{
23 „Uredba o uslovima i postupku za dozvoljavanje pobačaja“, Službeni list FNRJ, br. 9, (1960).

${ }^{24}$ I. Dobrivojević, $n$. d., 88.

${ }^{25}$ AJ, 142/II-623, Stenografske beleške sa sastanka održanog u Konferenciji za društvenu aktivnost žena Jugoslavije $u$ vezi sa pripremom savetovanja. Izlaganje dr Milojčića.

${ }^{26}$ AJ, 142/II-417, F. Novak, L. Andolšek, M. Kuštrin, I. Veter, Prikaz razvoja odnosa do celokupne problematike planiranja porodice u medicinskim krugovima. Savetovanje o izgradnji društvenih stavova o populacionoj politici u Jugoslaviji (1973).

${ }^{27}$ AJ, 142/2-658, Planiranje porodice - potreba savremenog društva.

${ }^{28}$ AJ, 142/II-391, Akcioni program za sprovođenje rezolucije Savezne skupštine o planiranju porodice.
} 
ceptivnih sredstava dodatno je slabio interesovanje za kontrolu začeća. Iako je kontracepcija trebalo da uđe u osnovni sistem zdravstvene zaštite i postane dostupna svakoj ženi, ${ }^{29}$ situacija u ovoj oblasti se često nije podudarala sa zaključcima usvajanim na raznim konferencijama i savetovanjima. Štaviše, sve do donošenja Rezolucije o planiranju porodice (1969), pravni propisi u vezi sa prekidom neželjene trudnoće imali su za cilj da stanu na put ilegalnim pobačajima i abortus ,presele“ u bolnice, ne bi li se tako minimizirao rizik po zdravlje žene. Stoga se putem propisa intervenisalo jedino kada je do neželjene trudnoće došlo, dok je u oblasti seksualnog vaspitanja ili razvijanja službe koja bi se bavila kontracepcijom zakonska regulativa izostala. ${ }^{30}$

Prva sredstva za kontracepciju pojavila su se u Jugoslaviji početkom 50-ih, ličnim zalaganjem dr Franca Novaka. On je 1950. godine boravio tri meseca u Engleskoj i Americi, gde se upoznao sa tadašnjim metodama kontracepcije. O svom trošku kupio je par kompletnih serija genofragmi, tada najboljih zaštitnih sredstava na tržištu. Jednu seriju je odneo u Savezno ministarstvo industrije, drugu kod ministra industrije Slovenije Franca Leskovšeka, a treću u fabriku gume „Sava“. Oba ministarstva su ispoljila interesovanje da pomognu, a rukovodstvo fabrike „Sava“ je obećalo da će početi sa proizvodnjom genofragmi, pošto budu nabavljeni federi iz Švajcarske i Švedske. Ubrzo se, međutim, ispostavilo da su mašine za preradu gume stare i tehnički neodgovarajuće za ovaj vid proizvodnje. Nabavljene su nove, čime je otpočela proizvodnja genofragmi u Jugoslaviji. Godine 1955. osnovano je prvo savetovalište za kontracepciju pri Centralnom ginekološkom dispanzeru u Ljubljani. Usledilo je otvaranje ordinacija na klinikama u Beogradu, Zagrebu, Sarajevu i Prištini. U početku deljene su uglavnom genofragme, da bi se postepeno prelazilo na razna hemijska sredstva, uglavnom paste koje su se pokazale nedovoljno pouzdanim. U strahu da bi nedovoljna pouzdanost mogla da kompromituje ovaj vid kontrole začeća, na ginekološko-akušerskoj klinici u Ljubljani otpočelo je 1954. godine testiranje kontraceptivnih sredstava po međunarodnim kriterijumima. Tokom 1959-1960. preko Crvenog krsta se nabavlja pena EMCO, 1960. stižu prvi oralni kontraceptivi, a uskoro se pojavljuju i intrauterini ulošci. ${ }^{31}$

Propagiranje kontracepcije, međutim, bilo je uglavnom kampanjskog karaktera, bez ujednačenog sistema za čitavu zemlju. Popularizacija kontracepcije i napori da se spreči neželjeno začeće, a samim tim smanji stopa pobačaja, počivali su pre svega na ličnom zalaganju i entuzijazmu pojedinih lekara. Štaviše, ni sama struka po pitanju kontraceptivnih sredstava nije bila jedinstvena.

${ }^{29}$ AJ, 142/II-623, Zaključci sa savetovanja po pitanju kontracepcije, Uredbe o postupku za vršenje dozvoljenog pobačaja i seksualnog vaspitanja, održanog u Beogradu od 7-9. maja 1958.

${ }^{30}$ AJ, 142/2-658, Planiranje porodice - potreba savremenog društva.

${ }^{31}$ AJ, 142/II-417, A. Milojković, G. Žarković, M. Džumhur, Historijat liberalizacije pobačaja u Jugoslaviji. Savetovanje o izgradnji društvenih stavova o populacionoj politici u Jugoslaviji (1973). Videti i AJ, 142/II-417, F. Novak, L. Andolšek, M. Kuštrin, I. Veter, Prikaz razvoja odnosa do celokupne problematike planiranja porodice u medicinskim krugovima. Savetovanje o izgradnji društvenih stavova o populacionoj politici u Jugoslaviji (1973). 
Sporenja među pristalicama i protivnicima ovog vida zaštite potrajala su sve do III kongresa ginekologa (1956) koji je prvi put usvojio kontracepciju kao profilaktičku metodu. Dve godine kasnije, na pomenutom savetovanju održanom maja 1958. postignuta je potpuna saglasnost lekara i predstavnika društvenopolitičkih organizacija i usvojen zaključak „da je kontracepcija jedino uspešno oružje protiv abortusa“. ${ }^{32}$

U periodu 1958/59. i 1960. zdravstvena služba je uložila napor da se najšira javnost upozna sa svim prednostima kontracepcije. Održavana su predavanja, izdavane popularne brošure, deljeni leci, a u kampanju su se, koliko je tema dozvoljavala, uključila i sredstva javnog informisanja. Savetovališta za kontracepciju osnivana su svuda, ali ovo zdravstveno-edukativno prosvećivanje ,nije bilo dovoljno intenzivno" da izgradi svest o opasnosti pobačaja i prednosti preventivnih mera. O stanju i problemima na području planiranja porodice svedočila je i anketa o liberalizaciji abortusa koju je sprovela Zora. Žene iz viših društvenih krugova nisu se o liberalizaciji otvoreno izjašnjavale, dok su radnice, koje su živele u teškim porodičnim, stambenim i materijalnim prilikama, bile za potpuno legalizovanje abortusa. Isticale su da savetovališta za kontracepciju ne funkcionišu. Imajući u vidu rezultate ove ankete, Savez ženskih društava Srbije je izdejstvovao kod Republičkog zavoda za socijalno osiguranje da se otvori više savetovališta za kontracepciju. ${ }^{33}$ Međutim, žene su nerado posećivale novootvorena savetovališta, uglavnom pod izgovorom da nemaju vremena niti novca da kupe najjevtinije zaštitno sredstvo. ${ }^{34}$ Štaviše, prema podacima iz 1962. godine svega 35.000 žena, od ukupno 4,5 miliona u generativnom dobu, upotrebljavalo je kontracepcijska sredstva. ${ }^{35}$

Odluka Saveznog zavoda za socijalno osiguranje (1963) kojom je predviđeno „da se sva sredstva daju ženama pod istim uslovima kao i ostali lekovi“ trebalo je da omogući veću dostupnost kontraceptiva. ${ }^{36}$ Interesovanje žena za kontracepciju je počelo rasti, a menjao se i odnos lekara i zdravstvenog osoblja prema ovom pitanju. Planiranje porodice postaje jedna od glavnih tema lekarskih savetovanja. Ginekolozi se više ne opredeljuju za ili protiv kontracepcije, već diskutuju za ili protiv određenog zaštitnog sredstva. Ipak, uprkos sve većem broju savetovališta, ${ }^{37}$ pomaci su bili zanemarljivi. Kampanja je pre svega bila usmerena na žene, a ne i na muškarce ${ }^{38}$ finansiranje kontracepcijske službe je

\footnotetext{
${ }^{32}$ AJ, 142/II-417, F. Novak, L. Andolšek, M. Kuštrin, I. Veter, Prikaz razvoja odnosa do celokupne problematike planiranja porodice u medicinskim krugovima. Savetovanje o izgradnji društvenih stavova o populacionoj politici u Jugoslaviji (1973).

${ }^{33}$ Neda Božinović, Žensko pitanje u Srbiji u 19. i 20. veku (Beograd: Devedesetčetvrta, 1996), 188.

${ }^{34}$ I. Dobrivojević, $n$. d., 91 .

${ }^{35}$ AJ, 142/II-417, F. Novak, L. Andolšek, M. Kuštrin, I. Veter, Prikaz razvoja odnosa do celokupne problematike planiranja porodice u medicinskim krugovima. Savetovanje o izgradnji društvenih stavova o populacionoj politici u Jugoslaviji (1973).

${ }^{36}$ AJ, 142/2-623, nezavedeno, bez datuma.

${ }^{37}$ Prema podacima iz 1970, u Jugoslaviji je radilo 178 savetovališta. AJ, 142/II-391, Izveštaj Regionalnom savetu Međunarodne federacije za planiranje porodice za region Evrope.

${ }^{38}$ AJ, 142/II-417, A. Milojković, G. Žarković, M. Džumhur, Historijat liberalizacije pobačaja u Jugoslaviji. Savetovanje o izgradnji društvenih stavova o populacionoj politici u Jugoslaviji (1973).
} 
ostalo neuređeno, zdravstveno osoblje nedovoljno kvalifikovano, asortiman kontraceptiva skroman, a njihova distribucija neodgovarajuća. ${ }^{39}$

Staviše, uprkos odmakloj modernizaciji društva, delimičnoj emancipaciji žena i sve češćem isticanju potrebe da se „razreši konflikt između učešća žena u proizvodnji i društvenim aktivnostima i njenih obaveza u materinstvu“, ${ }^{40}$ i početkom 70 -ih godina su opstajala patrijarhalna shvatanja. Savremene metode kontrole rađanja teško su prihvatane, naročito u ruralnim sredinama, a i pojedini lekari su imali izvesne rezerve prema ženama koje nisu želele brojno potomstvo. Pokazalo se tako da je ,ideja o ravnopravnosti bila sveprisutna tema, ali ipak nije uspela da prevlada tradicionalne koncepte života““. ${ }^{11}$ Navešćemo jedno netipično, ali svakako ilustrativno izlaganje doktora Pavla Stambolića, ginekologa u Lazarevcu. „Kao ginekolog sam svakodnevno u kontaktu sa velikim brojem žena“, govorio je doktor Stambolić na Savetovanju o izgradnji društvenih stavova o populacionoj politici u Jugoslaviji (1973). „Zapazio sam da one čine dve velike grupe suprotne u svojim težnjama u odnosu prema deci. Prvu grupu čine žene koje smatraju da su deca naša radost, sreća i nada. One nose u sebi nagon za rađanjem i gajenjem dece. Kad su deca u pitanju, one su gotove na svaku žrtvu, one se ne boje bolova, krvavljenja i komplikacija na porođaju, niti mukotrpnog života u vezi gajenja novorođenog deteta. Njima ne smeta oskudan život usled velikih troškova zbog ishrane, odevanja i školovanja dece. Odevene su vrlo skromno, imaju kratke nokte i grube ruke, zbog svakodnevnog pranja pelena i veša. Drugu grupu žena čine žene koje smatraju da radost i sreću u životu čine lepe haljine, auto, vikendica. One u sebi ne nose nagon za rađanje i gajenje dece i ne žele da ih imaju. One su lepo odevene, imaju negovane ruke, dugačke nokte i mašinu za pranje veša kod kuće“". ${ }^{2}$

Suočeni sa rastućim brojem pobačaja, ali i trendom liberalizacije abortusa koji je zahvatio gotovo čitavu Evropu, ${ }^{43}$ lekari i brojni društveno-politički radnici počeli su diskutovati o menjanju, odnosno prilagođavanju zakonodavstva novim prilikama. Javila su se i prva, u to vreme prilično usamljena mišljenja, o pobačaju kao o glavnom „krivcu“ niskog nataliteta u pojedinim krajevima. Neki su stoga zagovarali potpunu zabranu prekida trudnoće u krajevima u kojima je broj živorođene dece mali, dok su drugi podržavali potpunu libe-

${ }^{39}$ AJ, 142/II-417, F. Novak, L. Andolšek, M. Kuštrin, I. Veter, Prikaz razvoja odnosa do celokupne problematike planiranja porodice u medicinskim krugovima. Savetovanje o izgradnji društvenih stavova o populacionoj politici u Jugoslaviji (1973).

${ }^{40}$ AJ, 142/II-417, N. Petrić, Društveno-politički aspekt planiranja porodice u Jugoslaviji. Savetovanje o izgradnji društvenih stavova o populacionoj politici u Jugoslaviji (1973).

${ }^{41}$ Karl Kazer, Porodica i srodstvo na Balkanu: Analiza jedne kulture koja nestaje (Beograd: Udruženje za društvenu istoriju, 2002), 448. Navedeno u celini prema: Vera Gudac-Dodić, „Između javnog i privatnog: Tito o svakodnevici žena u socijalizmu“, u: Tito - viđenja i tumačenja, urednica Olga Manojlović Pintar (Beograd: INIS 2011), 370.

${ }^{42}$ AJ, 142/II-417, Savetovanje o izgradnji društvenih stavova o populacionoj politici u Jugoslaviji (1973).

43 Abortus je dozvoljen u Velikoj Britaniji 1967, Francuskoj 1974, Italiji 1979, Španiji 1985; D. Herzog, op. cit., 59-160. 
ralizaciju abortusa. ${ }^{44}$ Umešala se i Rimokatolička crkva koja je oktobra 1968. zatražila potpunu zabranu prekida trudnoće, čak i iz medicinskih razloga, kao i, ukoliko bi bio dozvoljen pobačaj, davanje prava zdravstvenim radnicima katolicima da ne učestvuju u njegovom izvršenju. Sekretarijat Saveznog saveta za planiranje porodice odbio je ove zahteve, karakterišući ih kao ,pokušaj mešanja crkve u poslove države, položaj porodice i samoupravna prava građana i institucija“". 45

Novim Opštim zakonom o prekidu trudnoće koji je sadržao sve vrste indikacija za prekid trudnoće, uključujući i individualnu (1969), ${ }^{46}$ država je neki način priznala da dotadašnji rad na edukaciji stanovništva i širenju kontracepcije nije dao željene rezultate. O (ne)uspehu državnih napora na zdravstvenoprosvetnom planu, rečito je svedočila i anketa koju je sproveo Centar za demografska istraživanja pri Institutu društvenih nauka (1972) na reprezentativnom uzorku od 8.000 žena fertilne dobi. Dobijeni rezultati su pokazali da je $24,58 \%$ žena znalo za intrauterina sredstva, $32,43 \%$ za kondom, $66,68 \%$ žena za pilule $i$ $77,57 \%$ za prekinuti snošaj. Štaviše, žene su se o kontracepciji informisale, pre svega, preko prijateljica, muževa i štampe. Kao svojevrsni kuriozitet može poslužiti i podatak da se majka kao izvor informacija javljala samo u $0,64 \%$ slučajeva. ${ }^{47}$ Indikativno je i da su se, uprkos brojnim napisima u štampi koji su obrađivali različite probleme iz oblasti reproduktivnog zdravlja i planiranja porodice, ${ }^{48}$ mišljenja i saveti stručnjaka, pre svega ginekologa, veoma retko mogli čuti u javnosti budući da su ih novinari, gotovo po pravilu, zaobilazili. ${ }^{49}$ Dešavalo se da se u popularnim člancima ove vrste plasiraju i delimične istine, pa je ,štampa svojim nekontrolisanim pisanjem o štetnostima oralnih kontraceptiva napravila veliku zbrku i pometnju u korišćenju kontraceptivnih metoda“" ${ }^{50}$ Fabrika Ris je godinu dana bezuspešno pokušavala da na televiziji reklamira prezervative, a čak se i o aktivnosti državnih tela koja su radila na planiranju porodice jedva nešto znalo. ${ }^{51}$

Iako su socijalističke vlasti promovisale materinstvo i smatrale da ono ne može u potpunosti biti u domenu privatne sfere života žene, ${ }^{52}$ državna politika na

\footnotetext{
${ }^{44}$ I. Dobrivojević, $n$. d., 95.

45 AJ, 142/II-294, Stav Sekretarijata Saveznog saveta za planiranje porodice povodom zahteva Biskupijske konferencije Katoličke crkve u SFRJ.

${ }^{46}$ „Opšti zakon o prekidu trudnoće“, Službeni list SFRJ, br. 20, (1969).

${ }^{47}$ AJ, 142/II-417, G. Žarković, A. M. Džumhur, S. M. Džumhur, Š. Segetlija, M. Maglajić, A. Softić, Znanje, stavovi i praksa planiranja porodice kod ženskog stanovništva u fertilnoj dobi u Jugoslaviji. Savetovanje o izgradnji društvenih stavova o populacionoj politici u Jugoslaviji (1973).

${ }^{48}$ Videti: AJ, 142/II-623, Materijal objavljen iz oblasti planiranja porodice.

${ }^{49}$ AJ, 142/II-279, Stenografske beleške sa I sednice Saveznog zavoda za planiranje porodice (juli 1967). Izlaganje dr Berghofera.

${ }^{50}$ AJ, 142/II-417, A. M. Džumhur, G. Žarković, S. M. Džumhur, Upliv različitih metoda komunikacije na korišćenje usluga planiranja porodice u zdravstvenim ustanovama. Savetovanje o izgradnji društvenih stavova o populacionoj politici u Jugoslaviji (1973).

${ }^{51}$ AJ, 142/II-279, Stenografske beleške sa I sednice Saveznog zavoda za planiranje porodice (juli 1967). Izlaganje dr Berghofera.

${ }^{52}$ V. Gudac-Dodić, „Između javnog i privatnog: Tito o svakodnevici žena u socijalizmu“, 364.
} 
polju planiranje porodice u Jugoslaviji nikada nije imala za cilj regulisanje fertiliteta. Planiranje porodice, navodi Aleksandra Pavićević, nije bilo u prvom trenutku „koncipirano kao žensko pravo niti je bilo usmereno ka emancipaciji žena, nego ka razotuđenju porodice, u okviru koga je emancipacija žene od potčinjenosti tradicionalnim modelima ponašanja i uloga imala značajno mesto “. ${ }^{53}$ Nastojalo se da svako rođeno dete bude istovremeno i željeno ali je isticano i da ,prirodna želja čoveka za potomstvom“ ne treba da postane ,izvor nemaštine“. ${ }^{54}$ Godine 1963. osnovan je Koordinacioni odbor pri Konferenciji za društvenu aktivnost žena Jugoslavije koji je na saveznom nivou organizovao i usmeravao legislativnoprosvetno-zdravstvene aktivnosti u oblasti planiranja porodice. Paralelno sa radom na prevenciji neželjene trudnoće, ovo telo je, sa većim ili manjim uspehom, koordiniralo aktivnosti različitih organizacija i institucija u razvijanju službe zadužene za kontracepciju, ali i podsticalo delatnost u oblasti seksualnog vaspitanja mladih. Jugoslavija je 1965. bila domaćin Prve svetske konferencije o stanovništvu, a 1967. jedna od potpisnica Deklaracije o stanovništvu u kojoj je neracionalno povećanje stanovništva okarakterisano kao svetski problem. ${ }^{55}$

Planiranje porodice je u prvoj polovini 60-ih godina postalo i opštedruštveno, a ne samo zdravstveno pitanje. Iako je postojao opšti konsenzus da je broj neželjenih trudnoća, a samim tim i broj pobačaja, moguće sprečiti boljom preventivom, putem seksualne edukacije i vaspitanja, proširivanjem službe zdravstvene zaštite majke i deteta, obezbeđivanjem šireg asortimana kontracepcijskih sredstava i organizovanjem odgovarajućih službi savetovališta, primena ovih načela u praksi je tekla sporo. Situacija se nije bitnije izmenila ni kada je Koordinacioni odbor prerastao u samostalno telo, to jest Savet za planiranje porodice (1967) u čiji sastav su ušli predstavnici čak 31 društvene i stručne organizacije, ustanove i institucije. ${ }^{56}$

Zadatak Saveta je bio da „u saradnji sa svim zainteresovanim faktorima obezbedi trajno praćenje i proučavanje odnosa među polovima i regulisanja rađanja, da podstiče društvenu aktivnost na rešavanju pitanja iz ove oblasti, da organizuje razmenu iskustava i da bude inicijator onih aktivnosti

${ }^{53}$ Александра Павићевић, На удару идеологија. Брак, породица и полни морал у Србији у другој половини 20. века (Београд: Етнографски институт САНУ, 2006), 186.

${ }^{54}$ AJ, 142/II-417, N. Petrić, Društveno-politički aspekt planiranja porodice u Jugoslaviji. Savetovanje o izgradnji društvenih stavova o populacionoj politici u Jugoslaviji (1973).

${ }^{55}$ А. Павићевић, н. д., 189.

${ }^{56}$ AJ, 142/II-279, Bilten broj 1 (1967). Članom 5 predviđeno je da u Savet uđu predstavnici JNA, Jugoslovenskog odbora za socijalni rad, Jugoslovenskog crvenog krsta, Jugoslovenskog udruženja za sociologiju, Konferencije za društvenu aktivnost žena Jugoslavije, Saveza ekonomista Jugoslavije, Saveza farmaceutskih društava Jugoslavije, Saveza lekarskih društava Jugoslavije, Saveza omladine Jugoslavije, Saveza sindikata Jugoslavije, Saveznog sekretarijata za zdravlje i socijalnu politiku, Saveznog zavoda za proučavanje školskih i prosvetnih pitanja, Saveznog sekretarijata za obrazovanje i kulturu, Saveza studenata Jugoslavije, Saveznog zavoda za socijalno osiguranje, Saveznog zavoda za zdravstvenu zaštitu, Udruženja farmaceutske industrije, Udruženja ginekologa i opstetičara Jugoslavije i Udruženje pedijatara; AJ, 142/II-279, Pravila Saveznog saveta za planiranje porodice. Bilten broj 1 (1967). 
koje će najviše doprineti formiranju progresivnih stavova i realnih programa značajnih za unapređenje delatnosti na ovom području“. ${ }^{57}$ Zajedno sa Konferencijom za društvenu aktivnost žena, Savezni savet za planiranje porodice je radio na uobličavanju stavova koji su poslužili kao platforma za donošenje Rezolucije o planiranju porodice (1969) koja je predstavljala svojevrsni nacionalni program. Ostvarivanje mogućnosti roditelja da sami određuju broj dece u porodici i razmak između porođaja definisani su kao ,jedno od osnovnih ljudskih prava“, koje je trebalo ostvariti upotrebom zaštitnih sredstava. U skladu sa ovim stanovištem, na pobačaj se gledalo kao na „krajnje sredstvo da se ženi omogući da prekine neželjenu trudnoću“. ${ }^{58}$ Nekoliko godina kasnije, pravo čoveka da slobodno odlučuje o rađanju dece ušlo je i Ustav (1974). ${ }^{5}$

Rezolucija, međutim, nije garantovala da će Jugoslovenkama biti pružene ,usluge kontracepcije takvog obima i takvih kvaliteta da bi pobačaj postao nepotreban““ ${ }^{60}$ Iako su savetovališta za kontracepciju, prema Zakonu o obaveznim vidovima zdravstvene zaštite, bile besplatne službe, republike su određivale različite cene za kontraceptivna sredstva. Tako su ona u nekim delovima zemlje bila potpuno besplatna, dok su u drugim žene participirale u troškovima kao i za lekove koji se izdaju na recept ili su pak plaćale punu cenu. ${ }^{61}$ Rezultati ankete sprovedene tokom 1973. godine u 739 zdravstvenih ustanova širom Jugoslavije (na upitnike je odgovorilo 360 ustanova, tj. 48,7\% anketiranih) pokazali su da je izbor kontracepcijskih sredstava siromašan, a da je socijalno osiguranje u ove svrhe izdvojilo svega $48 \%$ od planirane sume. Jugoslovenke su stoga bile prinuđene da se snalaze kako su znale i umele. Četvrtina žena $(25,1 \%)$ dobijala je zaštitna sredstva besplatno od lekara koji su ih prethodno dobijali od raznih firmi, dok je čak 26,9\% njih kontraceptive kupovalo od svog novca. Broj korisnica kontraceptiva je varirao od republike do republike. Prednjačila je Slovenija u kojoj je na 1.000 žena dolazilo 104,7 korisnica, dok je na Kosovu njihov broj bio daleko manji - svega $17,3 .^{62}$

Iako kontrola rađanja nikad nije bila smatrana instrumentom populacione politike, pomalo je paradoksalno da je aktivnost zdravstvenih ustanova, inače relativno nerazvijena na teritoriji čitave Jugoslavije, bila najslabija u oblastima

\footnotetext{
${ }^{57}$ AJ, 142/II-279, Pravila Saveznog saveta za planiranje porodice. Bilten broj 1 (1967).

${ }_{58}^{58}$ AJ, 142/II-342, Rezolucija o planiranju porodice.

59 Član 191 je propisao da se „ovo pravo može ograničiti samo radi zaštite zdravlja“. Уcmaв Соиијалистичке Федеративне Републике Југославије са уставним законом за спровођење устава Соиијалистичке Федеративне Републике Југославије (Београд: Службени лист, 1974), 115.

${ }^{60}$ AJ, 142/II-417, A. Milojković, G. Žarković, M. Džumhur, Historijat liberalizacije pobačaja u Jugoslaviji. Savetovanje o izgradnji društvenih stavova o populacionoj politici u Jugoslaviji (1973).

${ }^{61}$ I. Dobrivojević, $n$. d., 93.

${ }^{62}$ AJ, 142/II-417, G. Žarković, A. Milojković, M. Džumhur, Djelatnost zdravstvenih ustanova na planiranju porodice u Jugoslaviji (1973). Savetovanje o izgradnji društvenih stavova o populacionoj politici u Jugoslaviji (1973).
} 
sa najvišim fertilitetom - Bosni i Hercegovini, Makedoniji, Kosovu i Crnoj Gori. Štaviše, manjak lekara specijalista u ovim republikama je dodatno onemogućivao sistematski rad na propagiranju kontracepcije, podizanju svesti o posledicama abortusa i seksualnoj edukaciji stanovništva. Stoga je, ističe se u jednom izveštaju, najveća slabost čitave strategije planiranja porodice bila upravo u tome što je celokupan rad na ovom polju prepušten uglavnom ginekolozima, dok su lekari opšte prakse, srednje i pomoćno medicinsko osoblje i socijalni radnici delimično ili potpuno zaobiđeni. ${ }^{63}$

Sve do raspada Jugoslavije, država nije uspela da značajnije smanji broj pobačaja i favorizuje druge metode kontrole rađanja ${ }^{64}$ Liberalizacija propisa $\mathrm{s}$ jedne strane, nedovoljna finansijska sredstva uložena u preventivu, nesistematski rad na seksualnoj edukaciji mladih, ali i teške socijalne prilike, stambena oskudica i prezaposlenost žena uzimali su svoj danak. Parovi su se sve češće odlučivali samo za jedno dete, pa su od 1968. godine pojedini stručnjaci povezivali dozvoljeni abortus sa smanjivanjem nataliteta u nekim delovima Jugoslavije i upozoravali na porast nataliteta na Kosovu. ${ }^{65}$ Štaviše, negativna demografska kretanja podstakla su Skupštinu Srbije da 1983. godine donese Rezoluciju o obnavljanju stanovništva koja je trebalo da doprinese promeni demografskih trendova, pre svega u oblastima tzv. uže Srbije. ${ }^{66}$ Rezultati su izostali, a diskusije o depopulaciji su nastavljene i u narednim godinama, odnosno decenijama.

\footnotetext{
${ }^{63}$ Isto. Videti i: AJ, 142/II-279, Bilten broj 1 (1967).

${ }^{64}$ Treba, međutim, pomenuti i slučaj Slovenije u kojoj su sistematski napori na edukaciji stanovništva dali opipljive rezultate. Od 1962. broj pobačaja u ovoj republici je stagnirao, da bi od 1966. počeo lagano opadati; AJ, 142/II-417, F. Novak, L. Andolšek, M. Kuštrin, I. Veter, Prikaz razvoja odnosa do celokupne problematike planiranja porodice u medicinskim krugovima. Savetovanje o izgradnji društvenih stavova o populacionoj politici u Jugoslaviji (1973).

${ }^{65}$ AJ, 142/II-417, F. Novak, L. Andolšek, M. Kuštrin, I. Veter, Prikaz razvoja odnosa do celokupne problematike planiranja porodice u medicinskim krugovima. Savetovanje o izgradnji društvenih stavova o populacionoj politici u Jugoslaviji (1973).

${ }^{66}$ А. Павићевић, н. д., 191.
} 


\section{REFERENCE}

- Božinović, Neda. Žensko pitanje u Srbiji u 19. i 20. veku. Beograd: Devedesetčetvrta, 1996.

- Drakić, Gordana. „Prekid trudnoće prema Krivičnom zakoniku Kraljevine Jugoslavije i projektima koji su mu prethodili“. Zbornik radova Pravnog fakulteta u Novom Sadu, br. 3, (2011), 533-542.

- Dobrivojević, Ivana. „Planiranje porodice u Jugoslaviji 1945-1974“. Istorija 20. veka, br. 2, (2016), 83-98.

- Gudac-Dodić, Vera. „Između javnog i privatnog: Tito o svakodnevici žena u socijalizmu“. U: Tito - viđenja i tumačenja. Urednica Olga Manojlović Pintar, 360-371. Beograd: INIS, 2011.

- Gudac-Dodić, Vera. „Položaj žene u Srbiji (1945-2000)“. U: Žene i deca 4. Srbija u modernizacijskim procesima XIX i XX veka. Urednik nije naveden, 33-130. Beograd: Helsinški odbor, 2006.

- Gudac-Dodić, Vera. „Žena u socijalizmu: sfere privatnosti“. U: Privatnost kod Srba u dvadesetom veku. Urednik Milan Ristović, 165-204. Beograd: Clio, 2007.

- Herzog, Dagmar. Sexuality in Europe. A Twentieth-Century History. Cambridge: Cambridge University Press, 2011.

- Isić, Momčilo. „Dete i žena na selu u Srbiji između dva svetska rata“. U: Žene $i$ deca 4. Srbija u modernizacijskim procesima XIX i XX veka. Urednik nije naveden, 131-159. Beograd: Helsinški odbor, 2006.

- Krivični zakonik za Kraljevinu Srba, Hrvata i Slovenaca. Beograd: Državna štamparija, 1929.

- Marković, Predrag. „Seksualnost između privatnog i javnog u 20. veku“. U: Privatnost kod Srba u dvadesetom veku. Urednik Milan Ristović, 101-128. Beograd: Clio, 2007.

- Pavićević, Aleksandra. Na udaru ideologija. Brak, porodica i polni moral u Srbiji u drugoj polovini 20. veka. Beograd: Etnografski institut SANU, 2006.

- Petrović, Aleksandar. Rakovica. Socijalno-zdravstvene i higijenske prilike, t. 2. Beograd: Centralni higijenski zavod, 1939.

- Popović, Ratibor V. Agrarna prenaseljenost Jugoslavije. Beograd: Geca Kon, 1940.

- Simić, Ivan. „Soviet Influences on Yugoslav Gender Policies, 1945-1955”. Doktorska disertacija. UCL 2015.

- Ustav Socijalističke Federativne Republike Jugoslavije sa ustavnim zakonom za sprovođenje ustava Socijalističke Federativne Republike Jugoslavije. Beograd: Službeni list SFRJ, 1974. 
IVANA DOBRIVOJEVIĆ, PhD, Senior Research Associate

Institute of Contemporary History

Belgrade, Republic of Serbia

ivanadobrivojevic@hotmail.com

\section{FOR DESIRED PARENTHOOD. \\ FAMILY PLANNING POLICY IN YUGOSLAVIA 1945-1974}

\section{Summary}

Although the socialist governments promoted maternity believing that it cannot be completely in the private sphere of women's life, state policy in the field of family planning never tried to regulate fertility. In the early 60 -ies, family planning became social, and not just a health issue. Although there was a general consensus that the number of unwanted pregnancies (and thus the number of abortions) should be prevented through sexual education, improvement of health care services for mother and child and by providing counseling and a wider range of contraceptives application these principles in practice was slow. Together with the Conference for Social Activity of Women, the Federal Council for Family Planning worked on shaping attitudes that served as a kind of platform for the adoption of the Resolution on Family Planning (1969) which was a kind of a national program. The right of the parents to determine the number of children in the family and the interval between births was defined as „one of the fundamental human rights“, which was to be achieved by using contraception. In accordance with this view, an abortion was defined as the „last means that would enable women to terminate an unwanted pregnancy." A few years later, the human right to decide freely on having children was included in the Constitution (1974).

KEYWORDS: Yugoslavia, State council for family planning, abortion, desired parenthood, Resolution on family planning 